Educational Research for Social Change (ERSC)

Volume: 7 No. 1, April 2018

pp. 30-45

ersc.nmmu.ac.za

ISSN: 2221-4070

\title{
"You Can't Write in Kaapse Afrikaans in Your Question Paper. . . . The Terms Must Be Right": Race- and Class-Infused Language Ideologies in Educational Places on the Cape Flats
}

\author{
Adam Cooper \\ Human Sciences Research Council and Education Policy Studies, Stellenbosch University \\ acooper@hsrc.ac.za
}

\section{Abstract}

Language is integral to educational processes because it forms the basis for classroom communication and the medium for knowledge transfer. However, language is imbued with race- and class-related ideologies: ideas about "proper" and "educated" uses of language. Language ideologies are shaped by the linguistic norms of powerful groups and are based on political rather than linguistic factors. In this paper, I explore how language ideologies operated in three educational sites on the Cape Flats. Multisite ethnography was used to research language ideologies in classrooms, amongst a hip-hop group, and at a youth radio show. Participants in the study spoke a variety of Afrikaans known as Kaapse Afrikaans, which differs from the standard Afrikaans inscribed in the school curriculum. The research showed that language ideologies were perpetuated through semiotic processes known as iconicity, recursiveness, and erasure. Through iconicity, Rosemary Gardens youths' language was inextricably linked to colouredness-a mixed race and language with low status attributed to both. Whereas standard Afrikaans was described as "pure, high, proper, and real," Kaapse Afrikaans was recursively depicted as "low, deficient and slang." These semiotic processes functioned to erase young people's use of language at schools, particularly repressing Kaapse Afrikaans in its written form. On certain occasions, the hip-hop group used language freely as they commented on their local environments. Powerful linguistic ideologies will continue to denigrate marginalised youth, even if radical teachers and hip-hop culture dismiss them. Educators should, therefore, both endorse the linguistic resources youth bring to classrooms and arm them with powerful forms of language and knowledge that hold power elsewhere.

Keywords: race, class, language ideologies, youth, Kaaps

Copyright: (C) 2018 Adam Cooper

This is an open access article distributed under the terms of the Creative Commons Attribution Non-Commercial License, which permits unrestricted non-commercial use, distribution, and reproduction in any medium, provided the original author and source are credited. 
Please reference as: Cooper, A. (2018). "You Can't Write in Kaapse Afrikaans in Your Question Paper. ... The Terms Must Be Right": Race- and Class-Infused Language Ideologies in Educational Places on the Cape Flats. Educational Research for Social Change, 7(1), 30-45. http://dx.doi.org/10.17159/2221-4070/2018/v7i1a3

\section{Introduction}

\section{Language Ideologies on the Cape Flats}

In this article, I explore language ideologies in three educational places that involved youth from one poor Cape Flats neighbourhood created during apartheid. Sites included classrooms at the local school, a hip-hop crew, and a youth radio show. Youth in the study predominantly spoke Kaapse (Cape) Afrikaans or simply, Kaaps. Kaaps is tainted with historically produced class- and race-based associations that intersect with powerful language ideologies, which affected how these young people's speech and potential were appraised in the different settings.

Language ideologies are influential ideas regarding the "correct," "appropriate," or "proper" ways in which language is expected to be used (Hornberger, 2000; McGroarty, 2010). These ideas are often linked to how powerful groups define linguistic norms, such that particular ways of using language appear to be universal and ahistorical (Blackledge \& Pavlenko, 2002; Blommaert, 1999; Woolard \& Schieffelin, 1994). Analysing language ideologies helps to unmask how ideas about language "masquerade as description while acting" (Woolard, 1998, p. 11) in the interests of powerful societal groups. The status of dominant groups is often legitimised by language ideologies that link forms of language with "typical" people and activities, portraying these language practices as more sophisticated and learned (Wortham, 2008). The consequence of this process is that powerful language-related ideas reproduce the social order by justifying existing hierarchies (Gal \& Irvine, 1995; Wortham, 2008).

\section{Standard Languages and Nation-States}

An influential language ideology emerged with the political, geographical, and cultural differentiation of Europe as new nation-states were justified by the one territory, one culture, one language ideology (Canagarajah, 2013; McGroarty, 2010). The idea, known as the Herderian triad, implied that languages are unchanging, bounded entities that should be kept apart because they belong to particular groups of people who reside in demarcated territories.

A related language ideology is the concept of the "standard" language, which promotes uniformity of circumscribed languages linked to specific groups of people and territories, deterring speakers from deviation (Milroy, 2001). The term, standard, also implies a degree of attainment: that a standard or benchmark has been reached, endorsing particular versions of language as more prestigious than other varieties (Hornberger, 2000; Milroy, 2001).

The emergence of standard language varieties associated with particular cultures and territories can be traced historically. In 16th-century France, the Parisian dialect was validated as "French," while other varieties were castigated as creole, patois, and informal language (Bourdieu, 1991). Standard English was based on speech in Oxford, Cambridge, and London (Mesthrie, Swann, Deumert, \& Leap, 2009). The standard language ideology promotes the interests of powerful societal sectors, endorsing their linguistic resources as the standard measure of competence, while supposed language mixing and creolised forms are depicted as inferior (Bourdieu, 1991). 


\section{Kaapse Afrikaans}

In South Africa, the standardisation of Afrikaans by whites excluded the Afrikaans spoken by nonwhite speakers (Webb, 2010; Willemse, 2013). In the late 19th century, a white Afrikaner movement campaigning for Afrikaans to be officially recognised culminated in this group's version of the language becoming a medium of instruction at schools from 1914 and, along with Dutch and English, an official national language in 1926. By contrast, the language of youth described here evolved from Dutch and English, indigenous Khoi and San languages, and the words of African and Asian slaves, including Portuguese creole (McCormick, 2002). These diverse peoples and languages interacted at the Dutch East India Company (DEIC) slave lodge, at DEIC employees' homes, and on farms. As many as five different languages were used in 18th-century Cape colony households (McCormick, 2002). The language inherited by the group researched in this paper is entangled with this social history of Cape Town.

The language used by young people in Rosemary Gardens is imbued with class- and raced-based associations. The neighbourhood was established between 1972 and 1974 for people classified as "coloured" by the apartheid government. Colouredness is generally perceived as "mixed race" in the popular imaginary, despite the notion of racial purity, for any group, being discredited (Adhikari, 2005; Erasmus, 2001). A language ideology, related to the standard language, is the idea that good quality languages should remain "pure" from contamination by other languages, especially those spoken by the working classes or people of colour (Woolard \& Schieffelin, 1994). Colouredness, conceived as a mixed race, with a mixed language, has led to the status of this group of people and their language being denigrated. Gal and Irvine (1995) would have called this an example of iconicity. These authors described two other semiotic processes related to language ideologies, namely, recursiveness and erasure. I use these three concepts extensively for analytical purposes in this paper.

\section{Semiotic Processes that Perpetuate Linguistic Ideologies: Iconicity, Recursiveness, and Erasure}

Language ideologies may be perpetuated in everyday exchanges through semiotic processes that justify ideas about the relationship between language and social status. Gal \& Irvine (1995) described three such semiotic processes: iconicity, recursiveness, and erasure. The way that shared social and linguistic characteristics become bound together to form an ideological representation that appears to be inherent is called iconicity. In this case, a semiotic process has led to an ideological representation of colouredness as a mixture that extends to both race and language.

Through erasure, linguistic practices are simplified and homogenised as certain people and groups become invisible, their internal variation explained away (Gal \& Irvine, 1995). In this way, threatening social and linguistic facts that militate against dominant ideological representations are actively repressed or removed.

Recursiveness refers to representations that repeatedly portray social and linguistic phenomena as oppositional. Ideological differences are maintained through bifurcated descriptions that recursively construct social and linguistic communities (Gal \& Irvine, 1995). For example, the supposedly pure, untainted, white Afrikaner version became the standard form to be used in schools, universities, and government due to this group's political aspirations and their racialised linguistic legitimacy. This version has been repeatedly referred to as suiwer or pure Afrikaans, recursively enhancing its legitimacy in opposition to the supposedly mixed Kaapse Afrikaans. However, in other less institutionalised spaces, Kaaps continues to flourish. As Bourdieu (1991) stated, the more formal the context, the more likely that standard varieties will have attained hegemony. Language ideologies, therefore, work in context specific-ways at national, global, and institutional levels, intersecting 
through everyday language practices that occur in local sites (Makoe \& McKinney, 2014; Woolard \& Schieffelin, 1994).

\section{Breaking the Lines Through Hip-Hop: Alternative Language Ideologies}

Hip-hop contains different language ideologies. Originating in the Bronx, hip-hop consists of rapping, DJing, breakdancing, and graffiti art (Chang, 2005). This youth subculture represents the reclamation of public space by black and low-income youth in the United States because they use language as they would on the streets-resisting, reinventing, and mixing linguistic traditions (Alim, 2009; Rose, 1991). Similarly, in Cape Town in the late 1980s, groups like Prophets of da City and Black Noise used hip-hop to connect with coloured and black youth (Haupt, 2001). These groups reclaimed and reinvented local languages, performing in Kaapse Afrikaans and nonstandard varieties of English, isiXhosa, and isiZulu (Haupt, 2001). Cape Town hip-hop crews have used language to create alternative language ideologies, asserting their linguistic resources and encouraging pride in a marginalised identity.

The ways that linguistic ideologies operate in formal and informal educational places are, therefore, shaped by historically contingent sociolinguistic processes that intersect with race and class. While certain language ideologies have been linked to processes of state making and protecting the interests of, for example, a white South African minority, spaces where hip-hop practices flourish are often influenced by radically different histories, values, and cultural assemblages. I have argued elsewhere that social factors that produce places have a profound impact on dialogue and learning (see Cooper, 2017). However, in this paper I focus on the role of language ideologies in shaping appraisals of young people's use of language, which in turn influences the value youth perceive these places to hold. Youth are unlikely to invest time and energy into contexts where they receive overt or covert messages that communicate that they are culturally or linguistically deficient, and that they and their families are likely to remain marginalised. The research question guiding this article was therefore to explore: "How did language ideologies operate in formal and informal educational places inhabited by Cape Town youth from one former coloured neighbourhood?"

How this was done is explored in more detail in the next section.

\section{Method}

\section{Multisite Linguistic Ethnography}

Three educational sites formed a multisite ethnography-a research method that juxtaposes, compares, and makes connections between interlinked settings, creating a "bigger" story about people moving through various places (Dimitriadis \& Weis, 2004; Hannerz, 2003; Marcus, 1995, 1998). Single site ethnography rigorously documents one site to illuminate the relationship between cultural context and broader socioeconomic and political formations (Willis \& Trondman, 2000). By contrast, multisite ethnography allows people, places, objects, and practices previously thought to be incommensurate, to be juxtaposed and compared (Hannerz, 2003; Marcus, 1995, 1998).

More generally, ethnography generates rich descriptions of particular contexts, documenting how people make meaning of their motivations, actions, and lives (Geertz, 1973). My focus on language was an attempt to understand, intimately, how people from Rosemary Gardens made meaning of, and in, their worlds. Following Marcus' (1998) challenge to multisite ethnographers to follow people, stories, and common themes, I chose the traditional educational site, the classroom, as the first place to research linguistic ideologies. While observing classrooms at Rosemary Gardens High School (RGHS), I serendipitously met the Doodvenootskap (DVS) rap crew. The group was involved in communitybased activities, with three members employed by a nongovernmental organisation (NGO) that 
conducted research on child participation at school. I was drawn to research DVS due to its members being outspoken, which struck me as very different from the silencing I witnessed in RGHS classrooms.

I was attracted to the youth radio show, in which seven RGHS students participated, because it comprised a form of what Ladson-Billings (1995) called culturally relevant pedagogy that connects with students' sociopolitical challenges. Youth Amplified utilised a form of critical pedagogy, exposing participants to materials that dealt with the sociopolitical contexts in which they lived (see Cooper, 2016). Participants engaged in debates and discussions, live on air, after watching documentary films or reading written texts prior to the show. These materials and activities were different to those at the school, providing another point of comparison. My goal was to try to make an explicit comparison of language ideologies between the three sites, a key strength of multisite ethnography (Weis \& Dimitriadis, 2008).

\section{The Research Sites: Rosemary Gardens and the Three Educational Places}

Census 2011 data showed that $98 \%$ of Rosemary Gardens residents classified themselves as coloured (Statistics South Africa, 2011). Eighty-one per cent of residents spoke Afrikaans as their first language, with $19 \%$ speaking English. This differed from data for Cape Town in which $36 \%$ spoke Afrikaans, $28 \%$ English, and 30\% isiXhosa.

RGHS suffered from high rates of school discontinuation, with 400 Grade 7 students but only 60 Grade 12 students registered in 2012-a consistent trend in recent years. However, the school had a number of vibrant activities and valuable resources. Afternoon activities included rugby, soccer, softball, and hip-hop dancing facilitated by young people who lived in the area. RGHS had computer laboratories, a library, and a gymnasium. A free meal was available to all students.

Four schools participated in the Youth Amplified radio show, including RGHS, an English medium but isiXhosa-dominant township school, and two English-medium schools that charged school fees at least 15 times higher than the other two schools. Participants arrived at the community radio station on Saturday mornings and engaged with materials including watching documentary films and news media, reading academic articles, as well as discussions with people like the junior mayor of Cape Town. Individual participants then generated questions relevant to the texts before choosing the best questions to form the basis for live discussions on air. The show was hosted by one of the participants.

DVS evolved through interactions between youth in Rosemary Gardens as they engaged with NGOs, other organisations, and local and international cultural influences. The crew did not have a physical location in which its activities took place and can, therefore, more aptly be thought of as a metaphorical site. The core DVS crew consisted of approximately eight individuals, but up to 30 youth were regularly involved in their activities. In terms of age, one older member was in his early 30 s and two others were in their 20s, with the remainder of the group comprised of people in their mid to late teens.

\section{Data Collection}

Data generated was qualitative, collected through observations, semistructured interviews, and focus groups. Each site involved participant observation. Participation does not necessarily compromise research data validity; immersion and varying degrees of membership within the group being researched can stimulate an insider's perspective (Angrosino \& Mays de Pérez, 2000; Werner \& Schoepfle, 1987). Observation was an important form of collecting data on language ideologies because reported information, such as data gleaned from interviews, may reflect perceptions rather than actual practices. 
Youth Amplified observations included joining participants at the show over a period of two years. I observed 16 teachers in their classroom environments. I did not record classroom sessions because I felt that this would intimidate educators. Instead, I sat at the back of the room and made notes, documenting instances when students spoke, the language that they used, and whether dialogue ensued. DVS invited me to attend events in the community. I observed them performing their lyrics and I watched the crew work at the high school. The lyrics on an album created by one member of the crew, but which the entire group helped to produce, also provided data for analysis.

Individual interviews were conducted with 20 Youth Amplified participants, six of the DVS crew, and 11 educators. Interviews were unstructured, attempting to make participants, especially youth, feel relaxed and engage in conversation. Teachers were asked to describe the school and students, how language affected student performance, and academic challenges students faced. Almost all of the teachers at RGHS would have been classified as coloured during apartheid. DVS was asked questions about their life histories, school careers, hip-hop, and language use in different sites. Youth Amplified participant interviews probed school careers, what students enjoyed about the show, perceptions of students from other schools, and their experiences of using language at Youth Amplified and at school. Lines of conversation initiated by interviewees were followed when these were relevant to the research question (Kvale, 1996; Maxwell, 1996). Interviews lasted one to two hours, were recorded and transcribed.

I conducted four focus groups with four RGHS students in each session. Grade 12 students were involved in these discussions, which explored what young people enjoyed about school, as well as their perceptions of learning and language use in educational places. Rosemary Gardens students were shy, with focus groups promoting comfortable dialogue, shifting the balance of power towards the participants, who had a numeric advantage, in comparison to individual interviews where there is one researcher and one interviewee (Madriz, 2000).

\section{Data Analysis}

A thematic analysis coded data through identifying recurring themes related to young people's use of language in each site (Braun \& Clarke, 2006). The research question-"How language ideologies operated in specific sites" - was used to generate themes deductively. I looked for instances of iconicity, recursiveness, and erasure (Gal \& Irvine, 1995), analysing how these semiotic processes operated and influenced participants. This produced information pertaining to the kind of language used in each setting and how these youth, their peers, and educators held and developed attitudes and evaluations of language use in different sites. It illuminated how topics were introduced and how regularly young people spoke. The analysis provided insight into the way that different themes operated in the data, the relationship between themes, and how the themes related to language ideologies, iconicity, recursiveness, and erasure.

Coded transcripts were then triangulated with the other data sources. If a theme was observed in Youth Amplified shows as well as in individual interviews, and aspects of this theme appeared in my field notes, it was identified as prominent. The operations of language in the three sites were compared and contrasted in this way.

Pertinent questions generated by ethnolinguists who have studied language in classrooms were also used. For example, "How are the languages/language varieties of different cultures recognized and used in schools?" "How does language promote learning, shared understanding and conceptual development?" "How does classroom language enable or inhibit the expression of identities?" (from Mercer, 2010, p. 2). Although these questions were intended for classroom research, I used them to 
analyse the data in each site, which enabled an analysis beyond simply describing language, to an account of how power, identity, and history intersected with language use.

\section{Ethics}

The research was approved by an ethics committee at the university where the researcher was based. All of the participants gave informed consent and all names of people and places are pseudonyms.

\section{Findings: Language Ideologies in the Three Places}

\section{Rosemary Gardens High School (RGHS)}

In the following focus group, students (S) said that the language they spoke at home was inappropriate for certain academic practices at school. The discussion related to the play, Krismis van Map Jacobs [Map Jacobs' Christmas, Small, 2008], a compulsory Grade 12 text written in Kaapse Afrikaans:

S1: In Krismis they speak like us. I can relate to them.

Interviewer (I): Is it important to read books like that?

S1: In a way yes and in a way no. That Afrikaans isn't right. It's not at the standard that it must be. You can't write in Kaapse Afrikaans in your [examination] question paper. The terms must be right.

I: Why?

S2: You can't mix your language. We can't speak like that. Your marks go down immediately. They will penalise you [repeats in English], they will penalise you.

(Translated from the Afrikaans, focus group discussion)

A student said "you can't mix your language" and that doing so during examinations would result in her being penalised. The mixed language referred to was Kaapse Afrikaans from Krismis van Map Jacobs, the version of Afrikaans students spoke at home. These sanctions by educators communicated to this student that her language was inappropriate for written work that would be evaluated, leading to her belief that you can't mix your language.

Another student said that the Afrikaans from the play "isn't right" and that it's "not at the standard that it must be." This implied that the language she spoke at home was inferior and that there was something "wrong" with it. The passage demonstrates how Kaapse Afrikaans undergoes erasure at school due to disciplinary practices like formal assessments. Students are deterred from writing in this language through academic penalties. Recursive constructions appear-such as standard Afrikaans being right and, by implication, students' language being wrong. The language learners spoke was portrayed as mixed, in comparison to the pure school version.

Another student recursively described school Afrikaans as "high":

The words are very high this year. We never hear those kinds of words. Everything we get is in Afrikaans but it's high Afrikaans. Not the Afrikaans that we speak. That's the Afrikaans that they train us in. It's the Afrikaans that we ought to speak.

(Translated from the Afrikaans) 
School Afrikaans was high, implying that the variety of Afrikaans spoken at home was "low." The phrase, "it's the Afrikaans that we ought to speak," insinuated that the use of high Afrikaans was legitimate as a medium of instruction at RGHS, and students were responsible for learning this version. This student did not say that different versions of the language were appropriate for various settings. A hierarchy existed: the language spoken at home wasn't right, it was lower in quality compared to the Afrikaans learned at school.

An educator also believed that students' language was inappropriate for written use at school:

The biggest problem is that learners come with a cultural deficiency. .. no books at home. The only proper English or Afrikaans they hear is from teachers. Their oral tradition is good, but we need to get them studying and reading. It's the basis of the education. Once they have good command of the language, they can be fine.

This teacher said students were culturally deficient and did not learn "proper" English or Afrikaans at home. Proper, meaning "genuine, acceptable or appropriate," insinuated that students' home language variety was "improper" and inferior in comparison to standard English or Afrikaans. Having access to books and gaining command of standard language can be highly beneficial. However, this does not mean that the language learners acquired at home was deficient or poor in quality. The teacher equated a lack of literacy resources with a deficient or improper linguistic repertoire, placing a value judgement on the child and his or her family.

The teacher associated studying and reading with gaining good command of the language. While students' home language was deemed appropriate for oral use, according to the teacher, literacy required the acquisition of a new set of language resources. Like the student who said that learners were penalised for using Kaaps in examinations, a language ideology appeared that implied that Kaaps was acceptable orally but unsuitable for written purposes.

A hegemonic language ideology was therefore observed amongst some students and educators at the school, endorsing standard Afrikaans as proper, high, and good quality. By contrast, these participants perceived students home language to be deficient, a mixture, and not right.

\section{Language Ideologies at Youth Amplified Radio Show}

Conflict occurred between two participants ( $G$ and $T$ ) at the radio show after the group watched Afrikaaps, a documentary that explored the possibility of using Kaapse Afrikaans at school:

G: You people in support of Afrikaaps do Afrikaans at school right? . . You say you understand Afrikaaps and that at school you do Afrikaans and so that's a problem for you 'cause you do your subjects in that language. So here's the solution then, eradicate Afrikaaps, do the formal Afrikaans as it should be, then you won't have a problem at school.

T: Why don't the teachers come down to my level?

G: No, it's not supposed to be like that.

T: Okay, they don't even have to come to my level, why don't they just find a slight way of changing how they explain things. 
G: That's the problem, you want to lower the standards, the standard has been set and now we want to lower it, it's wrong.

T: The thing is we are being taught, we have to learn to get to those standards. So they have to come to our standards to bring us up.

G: We wanna come and simplify Afrikaans in the most wrongest way by bringing this slang about. .. . Afrikaans is the formal language, it's the legal language, it has its own set of grammar and everything of how it should be spoken, now suddenly you want to come and say, "No it's a bit too difficult."

T: It's not that we want the language itself to change, but if the teacher finds a easier way of explaining, then we might learn the language better don't you think? Your maths teacher always finds some way for the slower child to catch up. So why can't your language teacher do that?

\section{G: So you saying the teacher should use some of your language in between?}

\section{$T: \ldots$ and then give us the real meaning afterwards. Don't you think?}

A student from one of the two high-fee schools argued that the language "standard has been set and now we want to lower it, it's wrong," implying that the Afrikaans standardised through the white Afrikaner political project, which became entrenched in the schooling system, set a standard that was supposedly lowered by students using other versions in class. Lowering the standards, therefore, meant endorsing other forms of Afrikaans that have historically been racialised and associated with coloured or black speakers.

Further justification for this racial-linguistic hierarchy was alluded to by the fact that standard Afrikaans was buttressed by it being "the formal language, it's the legal language, it has its own set of grammar." The use of a particular version of Afrikaans in the auspices of the state, the legal system, and other formal channels, was given as reason for its superiority. While the iconicity of Kaaps was associated with a coloured mixture, standard Afrikaans was iconically linked to the organs of power, like the legal system. In contradistinction to the formal, legal language, Kaaps was described as slang, with overtures of informality, verbal rather than written usage and colouredness.

Once the student, who I will call Greg, introduced the ideology of language standards, participants did not interrogate this concept; the criteria that constitute high standards were not explored. Instead, the group debated whether educators should accommodate students' apparently substandard language. Tracey, a RGHS student, argued that educators should descend to students' level, helping to uplift these young people intellectually and linguistically. When Tracey referred to the real meaning, she implied that the language that she used was inauthentic and invalid. While standard Afrikaans was deemed to be real, her own version of the language was erased from the school space as somehow inauthentic. A spatial metaphor was used recursively to differentiate between a high and a low version.

Tracey stated that she was not implying that the language itself should change, but that it was in the pedagogical interests of the learners for the teacher to use language students understood. Her explanation indicated that she did not want to be perceived as problematically agitating for change, but that the use of Kaaps should be justified on educational grounds. She further explained her position using the analogy of mathematics, in which teachers apparently used a range of heuristic devices to aid learning. Tracey advocated for code switching, whereby educators could utilise both the students' language and the code endorsed by the school to support learning. However, code switching was not 
described as using different versions of the language, but rather as languages of different quality and sophistication, indicated by one language being on a different level and one as real and the other not. Greg and Tracey insinuated that RGHS learners' language was inferior to middle-class students' linguistic resources, and they did not expect educators to use this rich reservoir of local words and knowledge in classrooms.

The verbal exchange at Youth Amplified radio show demonstrated how standard Afrikaans continues to be iconically associated with the state, its powerful institutions, and practices in postapartheid South Africa. This was recursively portrayed in comparison to Kaaps, which was denigrated as low quality slang.

\section{Language Ideologies Amongst the Doodvenootskap Hip-Hop Crew}

DVS used the following lyrics in their performances in the community and at various hip-hop venues in Cape Town. These lyrics also formed part of an album called Skollyhood, which the group selfproduced and sold at events:

My self-confidence se boosters het bruises, ek is 'n problem as ek wil unique is.

[My self-confidence boosters have bruises, I am a problem if I want to be unique.]

Babies lost their toys want their tannies wil rattle.

[Babies lost their toys because their mothers want to rattle.]

Organisations are competing, doing it for charity.

Ek is not van Bollywood or van Hollywood, ek is straight uit die Skollyhood.

[I am not from Bollywood or Hollywood, I am straight out of the Skollyhood.]

My porridge bowl is nou 'n satellite dish.

[My porridge bowl is now a satellite dish.]

Decisions word gemaak sonder ons en nou moet ek my bek hou, in nowadays se status baie mense kyk op na jou en jy's ' $n$ infection, you were born from ' $n$ weak reaction.

[Decisions are made without us and now I must shut my animalistic mouth, in nowadays status many people look up to you and you're an infection, you were born from a weak reaction.]

These lyrics illustrate how DVS used hip-hop to assert their language and reflect on their lives. English and Afrikaans were seamlessly amalgamated, for example in Line 1, interspersing different languages almost on a word for word basis. This lyric is a reference to recreational drugs ("self-confidence boosters"), which leave their mark, metaphorically and literally, bruising the young rapper. Through the comfortable use of the language that he spoke at home, the young man reflected on his life choices.

The next line comments on mothers' resources being utilised for personal entertainment, instead of the developmental needs of their children. The word "rattle" contains a creative pun: a baby's toy but also the mother's pleasure in rattling or partying. This example shows how lyric writing enabled the 
group to use figures of speech in inventive ways as they made intelligent comments about their neighbourhood. Rather than seeing their language as inferior or lower, in this line it was used as a resource for social analysis.

DVS was aware of paradoxes related to NGO work in Rosemary Gardens, as demonstrated by Line 3. The irony of competing for charity was questioned given that charity is supposedly an altruistic act. The contradictions that globalisation has brought to Rosemary Gardens also impacted on this rapper's consciousness when he described (Line 5) rows of satellite dishes adorning houses and yet hunger is supposedly widespread. Satellite dishes allude to the fact that people in Rosemary Gardens aspired to watch international television channels when many residents did not have sufficient food to eat.

The album's title Skollyhood, referenced in Line 4, exemplifies the group reflecting on their cultural identities and using language unashamedly. Skollyhood is a portmanteau of the words "skolly" (a lower-class delinquent or ruffian) and Hollywood. This term illuminates an ambivalence between the Hollywood-like attention they received from youth in their neighbourhood and the public perception of themselves as common skollies from the infamous Rosemary Gardens, an area associated with gangsterism, substance abuse, and poverty.

While Tracey was reticent about appearing to be politically divisive at the radio show, DVS proudly proclaimed that others make decisions for them and that they are forced to shut their "beks" (a bek is the mouth of an animal). This is placed adjacent to a comment about these young people being perceived as an "infection ... born from a weak reaction." The line critiques public perceptions that young people represent social malaise and that they taint or pollute other parts of society. The reference to a weak reaction is a comment on racist stereotypes of colouredness as a mixture or impotence.

These lyrics therefore illuminated the group's uninhibited use of language through hip-hop. While they did not make explicit reference to the value of different varieties of Afrikaans, examples of the crew's speech illustrate that they used the language that they spoke at home confidently. Through hip-hop lyric writing, DVS provided evidence that they could express ideas without being deterred by language ideologies that assessed their words to be lower, improper, or deficient.

\section{Discussion}

Race- and class-based language ideologies prominently appeared in the speech of young people at RGHS, Youth Amplified, and amongst DVS, shaping perceptions of linguistic resources and educational potential. For example, at RGHS during a conversation related to the Afrikaans setwork play, Krismis van Map Jacobs, students differentiated between the relative worth of standard Afrikaans and the Kaapse Afrikaans spoken by students. Kaaps was described as not meeting the necessary standard for use at school, was thought to be mixed, and was considered illegitimate for school assessment tasks.

The concept of a mixed language is related to the powerful social representation of colouredness as mixed race, demonstrating iconicity (Gal \& Irvine, 1995). Through iconicity, ideological representations of working-class coloured youth are inextricably connected to denigrated forms of language deemed inappropriate for "studying and reading," as one teacher put it. Iconicity justified the semiotic process of erasure, through which the use of Kaaps was repressed at school, when students said "you can't mix your language" and "you can't write in Kaapse Afrikaans in your [examination] question paper," because "the terms must be right." 
The version of Afrikaans enshrined in the South African constitution and taught at RGHS is generally spoken by white South Africans, a language tainted by privilege and dedicated to linguistic (and racial) purity. Its legitimacy in South African classrooms is justified by racialised and class-based language ideologies because certain languages and people are deemed to be mixed and, therefore, required to adapt their language practices.

Iconicity and erasure were inextricable from recursiveness: the ways in which certain representations repeatedly portray social and linguistic phenomena as oppositional (Gal \& Irvine, 1995). Whereas Kaaps was mixed, standard Afrikaans was perceived as pure and fertile for written forms of knowledge generation. Mixed has connotations of an object that is diluted and not in its original, true form, whereas purity implies a version that is unadulterated and therefore more authentic. This was related to a range of other recursive linguistic constructions, such as school Afrikaans being high and Kaaps, low and some words at RGHS were considered right and others, by implication, wrong. School Afrikaans was proper whereas Kaaps was not.

Colonial and apartheid-era ideologies constructed through the intersection of language, race, and class therefore reproduced social and linguistic hierarchies at RGHS in the democratic period. This was particularly pronounced in relation to forms of written language. Students said that it was during written examinations that Kaaps was penalisable. An educator believed that students did not learn proper English or Afrikaans at home and that proper language was required to catalyse reading and studying.

Similar linguistic ideologies were observed at the youth radio show, demonstrating how dominant ideas may travel with students into informal educational settings. Standard Afrikaans was iconically associated with the state, including the legal system, justifying its hegemony in government-controlled spaces such as classrooms. It was warned that these standards could potentially be eroded in the postapartheid era.

Iconic depictions of the relationship between language, the state, and legitimate educational processes were justified by recursive distinctions. Whereas standard Afrikaans was depicted as formal, Kaaps was dismissed as slang, creating a binary between official language validated by the state and other supposedly informal forms utilised in less respectable places, like the street. Slang is generally used orally rather than in written form, reinforcing the idea that the literacy practices of the classroom should be sanitised from language used in less prestigious sites.

Similar forms of linguistic iconicity and erasure, linked to nation-state's policies, occur in other countries because nonstandard language practices are frequently perceived as mixtures that threaten "respectable" citizenship. The Singaporean government's Speak English Well campaign demonstrated resistance to creative, hybrid language like Singlish. Singlish, a mixture of Hokkien and English, was popular in Singapore (Rubdy, 2005). Indonesian nationalists have used the media and education to promote Indonesian, a specific, high variety of Malay developed under Dutch colonial rule. Other varieties and creolised versions of Malay are simultaneously suppressed (Ewing, 2005). States therefore play an active role in attempts to erase supposedly mixed varieties of language, asserting language ideologies that iconically depict respectable forms of citizenship as linked to particular languages.

Different semiotic processes were observed amongst the Doodvenootskap, who did not explicitly refer to language ideologies and correct or incorrect ways of speaking. Their written lyrics, which they performed in public spaces and recorded in the form of an album, consisted of language they spoke 
more generally. I have interpreted this as evidence that the group resisted dominant linguistic ideologies given that they did not try to change or sanitise their language for particular sites or people.

This resistance is supported by the fact that the DVS crew vehemently endorsed a range of local phenomena. As one member said, "why do we have to go across the world when we have everything here at home." This notion, sometimes referred to in South African popular discourse as "local is lekker (nice)," appeared in the way the group prioritised local events and trends as worthy of analysis, referring to their neighbourhood, its people and practices repeatedly in lyrics. DVS therefore endorsed local cultural phenomena, including the language that they spoke. Studies outside of the United States have generated similar findings, as artists translate hip-hop practices and values into new contexts, creating authentic, hybrid identities. Research in Tanzania, Senegal, Korea, and Malaysia illuminated how hip-hoppers initially mimicked American culture, before refining their practices to reflect local values, languages, and issues (Pennycook, 2007; Perullo \& Fenn, 2003).

DVS validated local linguistic practices and values, buttressing youth with confidence to speak in public places. Rather than their speech being linked to inferior forms of racialised and class-based stereotypes, the group positioned itself in relation to different public figures, symbols, and practicesconnecting their hip-hop and use of Kaapse Afrikaans with an authentic form of political activism and creative expression. As Shaheen, a member of another rap group, Prophets of da City, remarked in the 1990s:

When we do interviews and we speak gamtaal [Kaapse Afrikaans], that shit's on purpose so the kid at home can say, "Fuck they're speaking my language," you know? They're representing what comes out of the township... I I want some kid from the ghetto to think, "Naa, we can relate to that." (as cited in Haupt, 2001, p. 178)

Educational places that utilise practices like those contained in hip-hop culture may therefore function as resistance to the semiotic process of erasure: the eradication of linguistic facts that are inconsistent with dominant linguistic ideologies. Gal and Irvine (1995) described erasure as the process through which internal inconsistencies in ideological representations of difference are explained away and removed. Like the hip-hop practice of tagging walls through graffiti art, performing rap lyrics using local mixtures of historically oppressed languages functions metaphorically to tag the real and online spaces where youth perform, providing evidence that their language exists and that it is creative, thoughtful, and comprehensively educational.

This said, schools remain the sites that prepare youth with powerful languages and knowledges in order to strive for social mobility in places of employment and tertiary education institutions. Powerful linguistic ideologies will continue to operate, even if radical teachers and hip-hop culture dismiss them (Bourdieu, 1991). Educators should therefore endorse the linguistic resources youth bring to classrooms and arm them with powerful forms of language and knowledge that hold power elsewhere. This may be achieved with the aid of state-supported institutional mechanisms such as the legal system. For example, the Ebonics Debate in the United States led to an Oakland court ruling that some classroom instruction should take place in Ebonics or African-American Vernacular English (AAVE). More importantly, the court said that educators need to facilitate students' acquisition of standard English language skills and learn aspects of AAVE themselves (Delpit, 1997).

The Oakland court ruling was based on an acknowledgement that languages and language varieties do not differ in inherent quality, but are diverse cultural artefacts that are linked to norms and practices associated with particular places. Although all languages are mixtures, certain versions of language are regularly denounced by the apparatuses of the state due to political rather than linguistic factors (Gee, 
1990; Stubbs, 2002). Sets of words are linked, in different ways, to historical processes that intersect with race and class, imbuing these words with social value and significance. Educating teachers on these sociolinguistic insights, as well as how youth on the fringes of society navigate their complex linguistic worlds, is therefore an urgent priority (Paris, 2011). As indicated by Tracey at Youth Amplified, "it's not that we want the language itself to change," but that a range of linguistic resources can be used to enrich learning. Educators' explicit acknowledgment that diversity and difference are not synonymous with deficit can communicate to students that they are welcome, valued, and expected to excel at school. Eradicating teachers' and students' misplaced beliefs that students are culturally and linguistically deficient can bolster the confidence of learners, improve learning outcomes, and contribute to a more socially just society.

\section{Acknowledgement}

The support of the DST-NRF Centre of Excellence (COE) in Human Development at the University of the Witwatersrand, Johannesburg in the Republic of South Africa towards this research is hereby acknowledged. Opinions expressed and conclusions arrived at, are those of the author and are not to be attributed to the CoE in Human Development.

\section{References}

Adhikari, M. (2005). Not white enough, not black enough: Racial identity in the South African "coloured" community. Cape Town, South Africa: Double Storey.

Alim, S. (2009). Creating "an empire within an empire": Critical hip-hop, language pedagogies and the role of sociolinguistics. In S. Alim, A. Ibrahim, \& A. Pennycook (Eds.), Global linguistic flows: Hiphop cultures, youth identities, and the politics of language (pp. 213-230). London, UK: Routledge.

Angrosino, M., \& Mays de Pérez, K. (2000). Rethinking observation: From method to context. In N. Denzin \& Y. Lincoln (Eds.), The SAGE handbook of qualitative research (pp. 673-702). London, UK: SAGE.

Blackledge, A., \& Pavlenko, A. (2002). Ideologies of language in multilingual contexts: Special issue. Multilingua, 21(2/3), 121-326.

Blommaert, J. (1999). The debate is open. In J. Blommaert (Ed.), Language ideological debates (pp. 1-38). New York, USA: Mouton de Gruyter.

Bourdieu, P. (1991). Language and symbolic power. Cambridge, UK: Polity Press.

Braun, V., \& Clarke, V. (2006). Using thematic analysis in psychology. Qualitative Research in Psychology, 3(2), 77-101.

Canagarajah, S. (2013). Literacy as translingual practice: Between communities and classrooms. New York, USA: Routledge.

Chang, J. (2005). Can't stop won't stop: A history of the hip-hop generation. New York, USA: St. Martin's.

Cooper, A. (2016). "Youth amplified": Using critical pedagogy to stimulate learning through dialogue at a youth radio show. Education as Change, 20(2), 1-23.

Cooper, A. (2017). Dialogue in places of learning: Youth amplified from South Africa. New York, USA: Routledge.

Delpit, L. (1997). Ebonics and culturally responsive instruction: What should teachers do? Rethinking Schools Online, 12(1). Retrieved from:

http://Www.Rethinkingschools.Org/Archive/12 1/Ebdelpit Shtml 
Dimitriadis, G., \& Weis, L. (2004). Rethinking the research imaginary: Globalisation and multi-sited ethnographic approaches. In G. Dimitriadus (Ed.), Studying urban youth culture. New York, USA: Peter Lang.

Erasmus, Z. (2001). Introduction: Re-imagining coloured identities in post-apartheid South Africa. In Z. Erasmus (Ed.), Coloured by history, shaped by place: New perspectives on coloured identities in Cape Town (pp. 13-28). Cape Town, South Africa: Kwela.

Ewing, M. (2005). Colloquial Indonesian. In A. Adelaar \& N. Himmelmann (Eds.), The Austronesian languages of Asia and Madagascar (pp. 227-254). New York, USA: Routledge.

Gal, S., \& Irvine, J. (1995). The boundaries of languages and disciplines: How ideologies construct difference. Social research, 967-1001.

Gee, J. (1990). Sociolinguistics and literacies: Ideologies in discourse. London, UK: Falmer Press.

Geertz, C. (1973). The interpretation of cultures: Selected essays (Vol. 5019). Basic Books.

Hannerz, U. (2003). Being there . . . and there . . . and there! Reflections on multi-site ethnography. Ethnography, 4(2), 201-16.

Haupt, A. (2001). Black thing: Hip-hop nationalism, race and gender in Prophets of Da City and Brasse Vannie Kaap. In Z. Erasmus (Ed.), Coloured by history, shaped by place: New perspectives on coloured identities in Cape Town (pp. 173-191). Cape Town, South Africa: Kwela.

Hornberger, N. (2000). Bilingual education policy and practice in the Andes: Ideological paradox and intercultural possibility. Anthropology and Education Quarterly, 31(2), 173-201.

Kvale, S. (1996). Interviews: An introduction to qualitative research interviewing. London, UK: SAGE.

Ladson-Billings, G. (1995). Toward a theory of culturally relevant pedagogy. American Educational Research Journal, 32(3), 465-491.

Madriz, E. (2000) Focus groups as feminist research. In N. Denzin \& Y. Lincoln (Eds.), The SAGE handbook of qualitative research (pp. 835-850). London, UK: SAGE.

Makoe, P., \& McKinney, C. (2014). Linguistic ideologies in multilingual South African suburban schools. Journal of Multilingual and Multicultural Development, 35(7), 658-673.

Marcus, G. (1995). Ethnography in/of the world system: The emergence of multi-sited ethnography. Annual Review of Anthropology, 24(1), 95-117.

Marcus, G. (1998). Ethnography through thick and thin. Princeton, USA: Princeton University Press.

Maxwell, J. (1996). Qualitative research design: An interactive approach. Thousand Oaks, USA: SAGE.

McCormick, K. (2002). Language in Cape Town's District Six. Oxford, UK: Oxford University Press.

McGroarty, M. (2010). The political matrix of linguistic ideologies. In B. Spolsky \& F. Hult (Eds.), The handbook of education linguistics (pp. 98-112). Oxford, UK: Blackwell.

Mercer, N. (2010). The analysis of classroom talk: Methods and methodologies. British Journal of Educational Psychology, 80(1), 1-14.

Mesthrie, R., Swann, J., Deumert, A., \& Leap, W. (2009). Introducing sociolinguistics. Edinburgh, UK: Edinburgh University Press.

Milroy, J. (2001). Language ideologies and the consequences of standardization. Journal of Sociolinguistics, 5(4), 530-555.

Paris, D. (2011). Language across difference: Ethnicity, communication, and youth identities in changing urban schools. Cambridge, UK: Cambridge University Press. 
Pennycook, A. (2007). Language, localization, and the real: Hip-hop and the global spread of authenticity. Journal of Language, Identity, and Education, 6(2), 101-115.

Perullo, A., \& Fenn, J. (2003). Language ideologies, choices, and practices in Eastern African hip-hop. In H. Berger \& M. Carroll (Eds.), Global pop, local language (pp. 19-51). Mississippi, USA: University Press of Mississippi.

Rose, T. (1991) "Fear of a black planet": Rap music and black cultural politics in the 1990s. Journal of Negro Education, 60(3), 276-290.

Rubdy, R. (2005). Remaking Singapore for the new age: Official ideology and the realities of practice in language-in-education. In A. Lin \& P. Martin (Eds.), Decolonisation, globalisation: Language-ineducation policy and practice (pp. 55-75). Clevedon, UK: Multilingual Matters.

Small, A. (2008). Krismas van Map Jacobs. Cape Town, South Africa: Tafelberg.

Statistics South Africa. (2011). Report Name. Retrieved from http://www.statssa.gov.za/?page id=3955

Stubbs, M. (2002). Some basic sociolinguistic concepts. In L. Delpit \& J. Dowdy (Eds.), The skin that we speak: Thoughts on language and culture in the classroom (pp. 63-87). New York, USA: New Press.

Webb, V. (2010). Constructing an inclusive speech community from two mutually excluding ones: The third Afrikaans language movement. Tydskrif vir Letterkunde, 47(1), 0-0.

Weis, L., \& Dimitriadis, G. (2008). Duelling banjos: Shifting economic and cultural contexts in the lives of youth. Teachers College Record, 110(10), 2290-2316.

Werner, O., \& Schoepfle, M. (1987). Systematic fieldwork: Foundations of ethnography and interviewing. Thousand Oaks, USA: SAGE.

Willemse, H. (2013). Obituary: Jakes Gerwel (1946-2012). Tydskrif vir Letterkunde, 50(1), 126-131.

Willis, P., \& Trondman, M. (2000). Manifesto for" ethnography." Ethnography, 1(1), 5-16.

Woolard, K. (1998). Language ideology as a field of inquiry. In B. Schieffelin., K. Woolard, \& P. Kroskrity (Eds.), Language ideologies: Practice and theory (pp. 3-51). Oxford, UK: Oxford University Press.

Woolard, K., \& Schieffelin, B. (1994). "Language Ideology." Annual Review of Anthropology, 23(1), 5582.

Wortham, S. (2008). Linguistic anthropology of education. In N. H. Hornberger (Ed.), Encyclopedia of language and education (pp. 849-859). New York, USA: Springer. 